This item was submitted to Loughborough's Research Repository by the author.

Items in Figshare are protected by copyright, with all rights reserved, unless otherwise indicated.

\title{
Multinationals and skills policy networks: HRM as a player in economic and social concerns
}

PLEASE CITE THE PUBLISHED VERSION

https://doi.org/10.1111/1467-8551.12276

\section{PUBLISHER}

(c) British Academy of Management. Published by Wiley.

\section{VERSION}

AM (Accepted Manuscript)

\section{PUBLISHER STATEMENT}

This is the peer reviewed version of the following article: TREGASKIS, O. and ALMOND, P., 2017.

Multinationals and skills policy networks: HRM as a player in economic and social concerns. British Journal of Management, 30 (3), pp.593-609, which has been published in final form at https://doi.org/10.1111/14678551.12276. This article may be used for non-commercial purposes in accordance with Wiley Terms and Conditions for Use of Self-Archived Versions.

\section{LICENCE}

CC BY-NC-ND 4.0

\section{REPOSITORY RECORD}

Tregaskis, Olga, and Phil Almond. 2019. "Multinationals and Skills Policy Networks: HRM as a Player in Economic and Social Concerns". figshare. https://hdl.handle.net/2134/27594. 
Multinationals and skills policy networks

Multinationals and skills policy networks: HRM as a player in economic and social concerns

\section{Abstract}

This paper uses an embeddedness framework to reconceptualise HRM agency over the external labour market, and in so doing bring into focus the societal implications of HRM. Drawing on qualitative data from 53 key informants in two English regions, we identify the ways in which the subsidiaries of foreign multinationals (MNCs) engage with labour market skills actors. Our findings reveal how power structures are mobilised by local economic actors to align labour market skills with MNCs' demand priorities. We show that multinationals may seek to partially endogenize the resources of local labour markets when their competitive value is redefined in social as well as economic terms, and demonstrate that the social structure of subnational institutional governance arrangements and firm strategic action on skills creates the conduit through which resource endogenization may occur. Such structures potentially provide a space for social as well as economic concerns to be addressed, although the social structure of institutional arrangements may not prevent social concerns being overridden by economic priorities impacting the quality and value of skills.

KEY WORDS: Human Resource Management (HRM), International HRM, Networks, skills. 
Multinationals and skills policy networks

\section{INTRODUCTION}

Skills are central to firm competitiveness and the firm's control over these resources is a long-standing focus of strategic human resource management theorisation (HRM) (Beer, Boselie, and Brewster, 2015; Huselid, 1995; Michie and Sheehan-Quinn, 2001; Camps and Luna-Arocas, 2012; Tregaskis et al 2013). For multinational companies (MNCs), the opportunity to control resource and meet skills needs through location (and re-location) is a competitive feature of the multinational organisational form, enabling resource seeking foreign direct investors (FDI) to access and leverage locational resource advantages, some of which are derived from local labour markets (Gammelgaard, McDonald, Tüselmann, Dörrenbächer and Stephan, 2009; Almond, 2011; Buckley and Munjal, 2017). However, this ability to move and resource skills globally is a concern for policy makers in terms of job losses, downgrading of skills or under-employment and ultimately the ability to retain and attract -quality jobs (McDonald et al 2005). In the UK, poor productivity relative to other industrialised economies (Mason and Rincon-Aznar, 2015) suggests skill supply strategies alone are insufficient: rather high quality skills need to be interwoven with strategies around innovations in work organisation, capital investment and application of new technologies to maximise skill use (Keep, 2014). At the same time, political restructuring on devolution in the UK over several decades (Goodwin, Jones and Jones, 2005) has meant that the importance of FDI investment to local and regional economic development is particularly salient and increases the spatial complexity of state involvement in skills issues (Almond, Ferner and Tregaskis, 2015). We suggest the field of HRM has important questions to address, and a contribution to make, concerning its agency within the socio-political context (Almond and Ferner, 2006; Brewster, Wood and Brookes, 2008; Keep and Mayhew, 2010; 
Multinationals and skills policy networks

Martín-Alcázar et al (2008); Morgan and Kristensen, 2006; Muller, 1999; Tregaskis, Edwards, Edwards, Ferner and Marginson, 2010). Our work aims to contribute to this body of work.

The market and hierarchy explanations of economic action from which much of the theorisation on strategic HRM is derivative, fail to adequately account for dynamics between skills or policy actors and firms (Phelps, Valler, and Wood 2005; Phelps, MacKinnon, Stone, and Braidford, 2003; Monaghan et al., 2015). Whilst universalist approaches to HRM (e.g. Becker and Gerhard, 1996) exemplify least attention to contextual factors, contingency (e.g. Fombrun and Devanna 1984; Schuler and Jackson, 1987) and resource-dependency approaches (e.g. Barney 1991; Boxall, 1996) focus on human capital owned by the firm which they define narrowly as those inside the firm. This has meant that theoretically the boundary between what is identified as an internal (endogenous) and external (exogenous) resource, and thus what may be seen as the responsibility of the firm is artificially separated and fixed. This influences how the competitive value of labour market skill is understood in HRM theorisation. We look to social theories of economic behaviour associated with embeddedness theorists (e.g. Granovetter, 1985) to argue that labour market skill may in fact be partially endogenized by MNCs through social structures created by their engagement with regional skills policy networks. As a consequence we would expect a shift in the value and utilisation of this resource to the firm. We ask the question, under what conditions might firms seek to endogenize labour market skills?

This work makes three key contributions. The first is a theoretical contribution, whereby we demonstrate that conceptualising labour market skills as, at least, a partially endogenized, or owned, firm resource allows labour market human capital to be redefined $\underline{\text { in terms of its dual social and economic value, in a way that organisation centric models of }}$ 
Multinationals and skills policy networks

strategic HRM have failed to do. provides a fuller explanation of the nature of the

competitive value of this resource. It shifts the conceptualisation of labour market skills as a

from one of an external-resource to meet immediate skill gaps current needs and thus the

subject of extraction resourcing strategies, toward one where labour market skillis

conceptualised as an endogenous resource, in which the firm has a vested interest because

of its contribution to longer-term sustainable competitive advantage. $\underline{\text { A fundamental }}$

theoretical insight here is that the social structure that ties different constituents of the

$\underline{\text { skills networks, acts as a casual mechanism through which firms can take greater control }}$

and also responsibility for creating demand that yields social benefits. This identification of

$\underline{\text { social structure as a casual mechanism bridging economic and social interests and temporal }}$

concerns (i.e. immediate and longer term skill needs) elaborates the boundary conditions

necessary for latter conceptualisation allows for greater consideration of the social

structures that enable-co-creation of labour market skills. Second, we demonstrate

empirically how firms and policy actors are enabled and constrained in the extent to which

skill endogeneity occurs. We identify the role and features of sub-clusters within networks

which offset the competitive risks that might mitigate against collaboration on skills. We

also reveal how the motivation of 'moral' responsibility can take shape in tangible social

structures around a skills agenda leading to the identification of labour market skill as a

longer-term or sustainable strategic resource. Third, the results yield practice lessons for

policy actors and firms in areas where skills may currently be absent or evolving due to, for example, technological shifts.

The paper begins by theorising labour market skills as a talent resource for firms drawing on competing theoretical perspectives from hierarchy-market and embeddedness 
Multinationals and skills policy networks

theorists. We then explain the research context and methodology which uses a rich qualitative design to examine two regional skills networks. The data analysis draws on social network visualisation methods and content analysis to address the question of whether MNCs seek to endogenize labour market skills. The discussion draws out the implications of the work for theory and practice.

\section{Theorisation: Markets, hierarchies and skills}

Williamson's (1975) Markets and Hierarchies thesis reflects a new institutional economics explanation of economic action which has relevance here to our understanding of firm responses to labour market skills. Firm hierarchies are conceptualised as authority structures which are the most efficient for handling complex, ambiguous transactionspecific investments because they enable greater control and minimize opportunist behaviour between actors. Resources key to competitive advantage are brought within the control of the firm hierarchy. Markets involve inter-organisational arrangements, conceptualised as more efficient for dealing with standardised, non-complex transactions such as one-off purchases. Arrangements between firms are governed by formal contractual arrangements to prevent opportunistic behaviour. The way knowledge and skills, as resources, are controlled either through the firm or the market is argued, from such economic models, to be a function of their complexity or proximity to competitive advantage.

In the context of skills this theoretical framework is influential, as it permeates much of the later seminal theorising on strategic HRM (Becker and Gerhard, 1996; Fombrun and Devanna 1984; Schuler and Jackson, 1987; Boxall, 1996). Here boundaries between internal and external resources are clear and fixed with internal resources under the control of firm 
Multinationals and skills policy networks

structures of hierarchy and external resources controlled through market transactions and formal contracting arrangements. Talent strategies are conceptualised as internal firm processes concerned with some combination of internal labour market investment in developing employees through training and succession planning; and external labour market extraction or talent raids (Gardner, 2002) including aggressive recruiting direct from competitors, or shifting from local to global labour markets. This means models of HRM tend to treat labour market skills as an exogenous resource and thus our theorisation of firm strategies focuses on skill extraction and transactional contractual arrangements (Gardner, 2002). We suggest the over emphasis on firm hierarchy is too restrictive and simplifies the relationship between firms and labour markets and the implications this may have on how HRM academics theorise competitive resourcing.

Networks, labour market skills and MNCs

The hierarchy-market thesis has been countered by embeddedness theorists (e.g. Granovetter, 1985; Burt, 1983; Fligstein, 1990; 1996) who posit a different explanation of social action underpinning economic market transaction and argue action within networks of diverse stakeholders plays a significant role in influencing firm behaviour (Fligstein, 1990). Embeddedness arguments reflect a response to both the undersocialised conceptions of economic behaviour associated with Markets and Hierarchies (Williamson, 1975; Williamson and Ouchi, 1981) and oversocialised or normative explanations (Burt, 1982). Granovetter (1985) argues that these approaches led to the atomization of actors, or divorcing of actor action from social context, in a way that limits our understanding of economic behaviour: 'Actors do not behave or decide as atoms outside a social context, nor do they adhere 
Multinationals and skills policy networks

slavishly to a script written for them by the particular intersection of social categories that they happen to occupy [e.g. class or labour market position]. Their attempts at purposive action are instead embedded in concrete, ongoing systems of social relations' (Granovetter, 1985: 487).

We focus on the social relations within the skills network to identify features that might explain whether, and how, MNCs seek to influence external skills and so treat labour market skill as an endogenous rather than exogenous firm resource. A Granovetterian perspective would suggest that networks of social relations generate trust and minimize harm, and membership ties between actors and position of actors are central to our understanding. Members bring resource credentials that can include expertise, funding, and status. These actors are 'carriers of institutions, as they induce actors to conform to their norms and procedures (e.g. March and Olsen, 1989) and use their relative power vis-à-vis other organisations to enforce social order (e.g. Zucker, 1983)' (Fligstein and Sweet, 2002: 1211). The concrete ties between actors and the position held by actors in the network are also important in this conceptualisation. We have preferences for acting with those with a known reputation gained from historical ties and position within a network of relations. This means we may hear of the trustworthiness of an actor from others, or we can gain this information directly through contact. Personal, or direct, ties are considered effective because they provide a means of gaining information about other economic actors which is cheap to gain; if direct it is deemed more trustworthy and detailed than if gained from nondirect sources; a continuing economic relationship is likely to discourage untrustworthy behaviour as this could jeopardise future transactions. The membership, actor position and connections each provide an indication of how power is configured in the social structure. 
Multinationals and skills policy networks

For example, the centrality of actors, measured in terms of the number of connections an actor has relative to others, identifies their position in the co-ordination and flow of resources (Granovetter, 1985). The position of actors relative to each other also indicates whether a network represents an open or closed system (Granovetter, 1985). In open networks resource dependency amongst members is low (Yan, Francesco, Zhang and Chen, 2013), and transaction costs minimal as members do not expend excessive time on relationship management, as ties between actors are loose. Open network structures are often associated with knowledge or information sharing. Closed network structures depend on strong ties i.e. direct contact, resource interdependencies, mutual interests, high trust, and can give rise to the co-creation of knowledge (Coleman, 1988). Closed networks are useful in creating new knowledge, or collaborative learning, drawing on resources within the network (Coleman 1988), but their closed structure means they are selective in their membership (Yan et al 2013).

Ongoing economic relations build an overlay of social content and expectations of moral behaviour. These moral norms are strong forces in explaining collaboration in the absence of formal contracting arrangements. The strength of ties between actors indicated through concrete relationships is fundamental to collaboration, framing behavioural moral expectations, and legitimising action. But these same strong ties can lead to opportunism or fraudulent behaviour as actors collude to exploit gains at the cost of others. Therefore Granovetter and others (e.g. Fligstein) would argue that merely having the presence or absence of strong ties is not a sufficient condition to predict behaviour, instead it is important to understand the content of the social structure - in terms of who is involved, 
Multinationals and skills policy networks

what the motivations of influence are, how influence is exerted - to determine what outcome is found (Granovetter, 1985; 493).

The content of the social structure is important to explaining the internal dynamism of a network (Pemberton, 2000) and how power structures shape collaboration (Murmann, 2013). But equally in networks involving disparate members as in skills networks involving multinational and governance actors (M-GA) finding common ground for collaborative action may be difficult. Differing priorities and resource asymmetries, can impede the creation of the necessary social structure for collaboration (Tanis and Postmes, 2005; Marsh and Rhodes, 1992).

In the analysis that follow we consider the conditions under which firms may seek to endogenize labour market talent. We do this by analysing the embedded nature, i.e. power structure and content, of the network structure in two skills networks created around the attraction and retention of foreign direct investment (FDI) located within two English regions.

\section{RESEA RCH CONTEXT AND METHOD}

FDI institutional context in the UK and choice of regions

The UK provides an interesting context for exploring M-GA skills networks for a number of reasons. First, it is broadly a Liberal Market Economy (LME) (Hall and Soskice, 2001) where economic activity is largely driven by competition between firms with limited employment regulation. While this can be attractive to FDI, skills and education have long been a politically contentious issue, with the quality and volume of state investment significantly 
Multinationals and skills policy networks

lacking compared to other European countries. With little regulation mandating firm investment, the burden for skills investment has increasingly shifted to the employee (Keep and Mayhew, 2010). Second, increasing privatization of education and skills provision and shrinking public funds has reduced the power of governance actors to influence labour market skills (Keep, 2014). Third, industrial strategy by firms located in the UK promotes an over-reliance on low-skilled, service sector work (Phelps, 2008). Fourth, the FDI institutional context is complex and suffers from instability arising from incompatible political ideologies underpinning regional growth strategies which threaten to dismantle policy delivery mechanisms on 5 yearly election cycles (Marsh and Rhodes, 1992).

The Labour government (1997-2010) attempted to organize regional economic development around Regional Development Agencies (RDAs). Different directorates within RDAs were responsible for coordinating activities such as the attraction and retention of inward investment, skills development, employability and innovation. The subsequent abolition of these bodies by the $2010-15$ coalition government itself attests to the instability of institutions in the UK (dramatically underscored by the consequences of the EU referendum, which however is subsequent to the current analysis).

At the time of fieldwork there were substantive economic governance roles for 9 regions within England. We focussed on two, which provided variety in regional contexts, but ensured the data analysis remained manageable. The two regions selected provide a contrast in terms of the profile of MNC presence in the region. In Region 1 (R1) there was a growth in high-tech firms and the RDA had identified R\&D skills to support high tech firms as a strategic priority. The region also had a spillover of manufacturing from a neighbouring region where manufacturing was more dominant. Region 2 (R2) was an economically 
Multinationals and skills policy networks

deprived area of England with more localities having Assisted Area (AA) status that allowed European and state aid without compromising the integrity of the EU common market treaty. It was reliant on manufacturing based FDI and the associated Jobs and skills were a priority for the RDA.

\section{Data Collection and representation}

The research used a qualitative design. Interviews examined the social structure of voluntary (i.e. non-contractually defined) relationships between multinationals and governance actors looking at who was involved on a skills agenda, the focus of discussion, how ties were created/maintained and outcomes. Social network visualisations mapped ties between members and allowed a systematic representation of the power structure to complement interviews. Documentary evidence elaborate on the role of firms and governance actors in the locality and was used to confirm node attributes in the network visualisations. Safeguarding for reliability and validity of data were addressed in line with Eisenhardt and Graebner (2007) and thematic analysis in line with Miles and Hubermann (1994).

In total 51 semi-structured interviews were conducted with 53 respondents: 25 interviews in R1, 18 in R2, and eight extra-regional for example with representatives from institutions with a national remit; 35 interviews were with governance actors and 16 with MNCs. The MNCs were identified by the Regional FDI agency as 'lead' investors in the region. In R1, 6 firms including 4 small and medium high-tech firms and 2 large manufacturing firms participated. The high-tech firms all depended on skilled personnel recruited from local universities or from national and international labour markets. The manufacturing firms were high profile employing 700 and 3,500 regionally and several 
Multinationals and skills policy networks

thousand across the UK. These firms relied on traditional skilled labour, had strong internal training resources, but faced skills shortages from emerging technologies. Ownership included three Japanese, one Indian, one US, and one French. R2 included four of the largest employers in the region: two auto manufacturing businesses employing approx. 3,500 to 4,000 permanent employees respectively; two aviation manufacturing businesses employing approximately 800 to 6,000 permanent employees respectively. All employed several thousand employees across the UK. Ownership included 2 US, 1 German and 1 French firm. For each of these subsidiaries, technology changes associated with the materials used in aerospace and electric engine technologies in automotive was creating key skills challenges arising from the lack of formal qualification or training and high national demand for limited skills. High skilled employees were therefore able to move around employers regionally and nationally making retention difficult. Firms relied on skilled apprenticeship based labour drawn from local labour markets. Each of the firms had been present in their locations between 70 and just over 100 years.

MNCs interviews were conducted with senior HR managers or senior management with HR responsibilities at board level: tenure with their firms ranged from 10 to $40+$ years. On occasion 2 respondents per company with interviewed. Respondents contextualised the current talent issues they faced relative to previous experiences and many spoke of the interconnectedness between changing market demands, technological advances and their firm's talent strategies.

The interviews covered: career history, role responsibilities, organisational structure, FDI networks the organisation was involved with, members, purpose and outcomes of network activity, relationships with other network members. To illustrate how the networks 
Multinationals and skills policy networks

operated in practice respondents were asked to draw on specific examples of collaborative projects. All interviews were conducted by two researchers, recorded, transcribed and sense checked with participants.

The data used for the Social Network Analysis (SNA) were collected at the time of interview. Membership of the skills network was drawn up based on a combination of preliminary interviews with representatives of the RDA and analysis of secondary data sources including website materials and policy reports (Wasserman and Faust, 1994). The policy boundary for the SNA was labour market skills. Respondents were asked to identify collaborative activities between MNCs and governance actors relating to 'skills, training and development, as well as other core labour market competencies that multinational companies require for their competitive advantage.' The initial list of network members acted as an interviewer prompt. The interviews were used to draw up a SNA data matrix indicating network membership and presence or absence of a tie amongst network members. A full list of the types of network actors is represented in Appendix Table A1. The purpose of the SNA data was to provide systematic visual presentation of the networks in terms of the types of actor interests and the structure of the connections between those.

The software package UCINET was used to interrogate the data using the SNA method (Wasserman and Faust, 1994). This method can be used to provide insight into the attributes and relationships of actors, which can be represented graphically through nodes and ties respectively. Nodes represent the actor and their attributes (e.g. policy maker, policy implementer, governmental actor, educational actor). Ties are the links between the actors. 
Multinationals and skills policy networks

\section{Research Results}

Our analysis begins with an examination of the power structures of MNC-governance skill networks using social network visualisation tools. The analysis extends by examining the social content of these networks and the impact this has on MNC control over labour market skill.

\section{Network Structure: Power}

We measure power through three theoretically driven organising concepts discussed previously i.e. network membership; actor position; and actor connections.

The membership composition was complex and to the best of our knowledge, not previously systematically visualised in research on regional skills. Seven distinct actor groups representing different priorities and interests (based on company report, website details and interviewee descriptions) of around 70 actors in each region. These actor types included MNCs; central government departments for trade and industry and foreign direct investment (FDI) and national qualification bodies; regional government administration for delivery on economic growth, regional skills and employment bodies, regional union branches; Higher education and further education institutes; national employer-led bodies e.g. Confederation of British Industry; and local governance actors such as local authorities, chambers of commerce. These actors are significant high status organisations and representative bodies of both private and public sector interests, or 'carriers of institutions' to use Fligstein and Sweet's terminology. As such the potential for competing interests is considerable and its complexity raised as problematic to navigate by MNCs. This diversity in 
Multinationals and skills policy networks

the network can be seen visually in Figures $1 \mathrm{a}$ and $1 \mathrm{~b}$ where the symbols represent the different types of actor and the line represent the ties between actors: Figure 1a represents the connections between actors in Region 1 (R1) (72 nodes which represented each different actor, who were each connected through 263 recorded ties) and Figure $1 \mathrm{~b}$ represents those for Region 2 (R2) (64 nodes and 239 ties).

Table A1 illustrates how the 7 types of actors were distributed across the regions suggesting some important distinctions. R1 had a higher proportion of lead MNCs involved in the network: $15 \%$ compared to $9 \%$ respectively. Those in $\mathrm{R} 2$ were concentrated within manufacturing - but not direct competitors - were medium to large employers and attracted Members of Parliament for visits and openings. R1 by contrast had a greater range of MNCs from different sectors, who had a diffuse set of skill concerns and talent attraction strategies. There was a higher proportion of skills providers i.e. universities, colleges and trainers (R1 11\% vs. R2 8\%) again reinforcing the potential for resource duplication and competition. There were marked distinctions in the presence of local political and business partnerships: R2 had twice the proportion of active strategic partnerships ( $6 \%$ of the network) involving the local council and private businesses set up to address local regeneration. Engagement in these partnerships was voluntary, but described as something several MNC subsidiary managers felt was morally important given the social deprivation in the area. R2 also had a designated team within the regional development agency focusing on FDI attraction for the region, and given the significant FDI in the region, the UKTI also had a unit focused on investments in the region. These governance structures were not present in R1: FDI was diffused within the broader remit of the agency. Devolution to the regions of 


\section{Multinationals and skills policy networks}

responsibility for some aspects of economic development manifest in quite different subnational governance arrangements around FDI in turn impact on the skills network.

Figure 1a: Graphical Representation of the skills actor network in Region 1

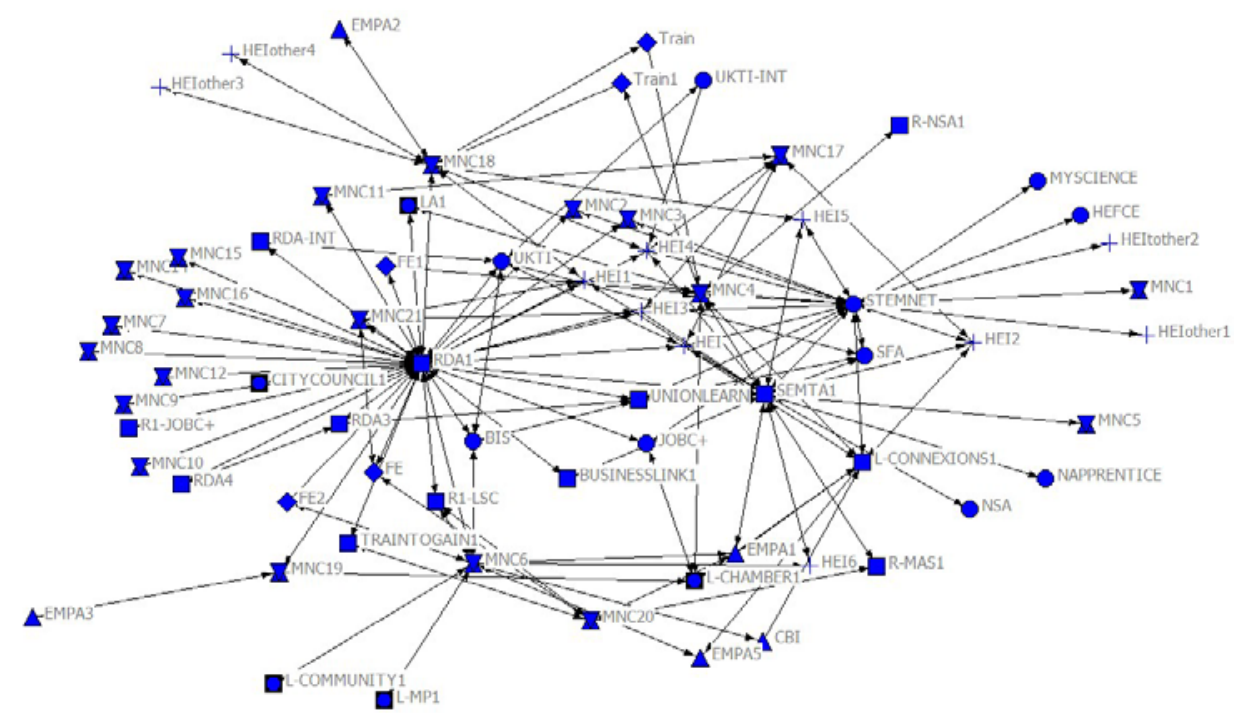

Figure 1b: Graphical Representation of the skills actor network in Region 2. 


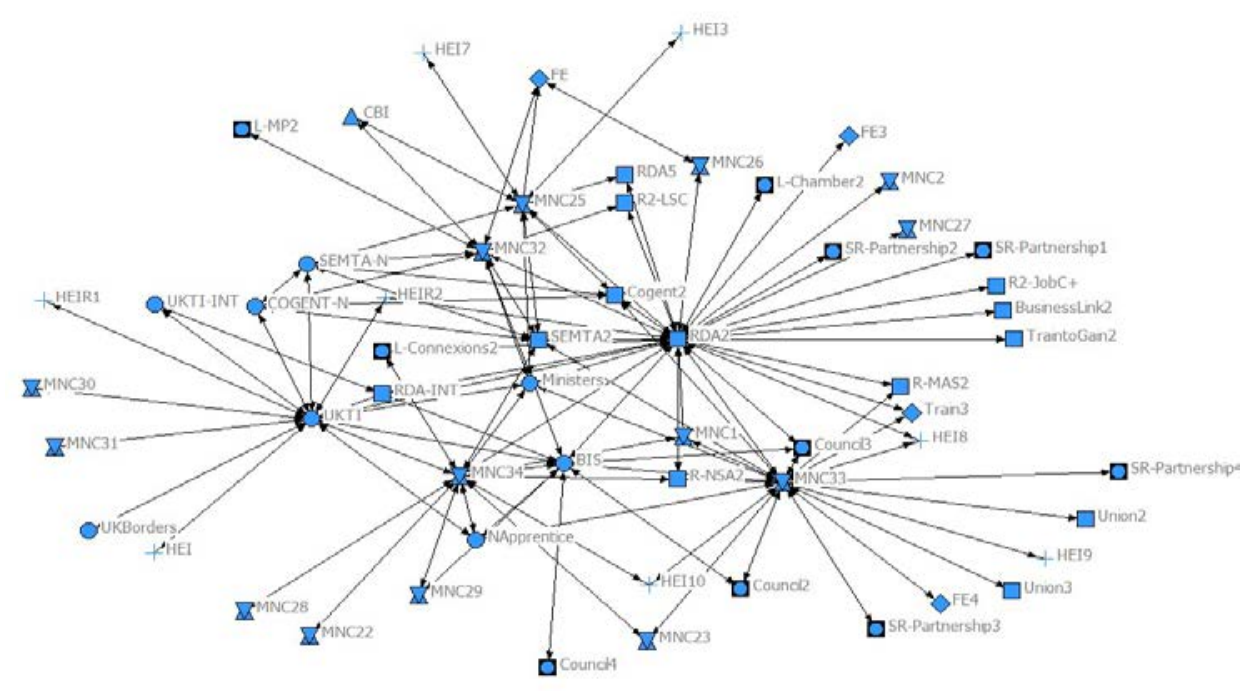

Actor position in the co-ordination of resources in the network elaborates on the power structure (Table 1 and Figures $1 \mathrm{a}$ and $1 \mathrm{~b}$ ). In R1 regional level governance actors (e.g. RDA, regional sectors skills bodies and Connexions) alongside STEMNET at the national level, and three multinationals (MNC4, MNC6 and MNC18) took on central positions. Direct ties around MNC18 were with universities, training organisations and the RDA; MNC6 the direct ties connect to local partnerships, other MNCs and the RDA; MNC4 had direct ties to a different set of education providers and SEMTA. The MNCs are not in direct competition for the same skills providers, and the governance actors indirectly tie the diverse interest groups. The presence of regional governance actors and participation by regional MNCS indicates a strong regional resource space, with direct central government absent. The central role of STEMNET and Universities reflected the focus on scientific skills to support high-tech subsidiaries. Universities and STEMNET were concerned with ensuring the scientific knowledge base kept pace with global developments as this knowledge base was seen as a locational advantage for FDI to the UK, and talent to the UK. Involvement of the 
Multinationals and skills policy networks

subsidiaries with universities and STEMNET enabled them to access global talent but also to influence and learn from advances in global sciences. The central role of technology focused governance actors reflected one strategic priority of the RDA and an occupational skills issue that spanned many firms, but it was not the sole concern of firms in the region. This suggests the network may work better for those with a common interest in technologybased skills and less well for other firms.

Table 1: Summary of the number of ties ${ }^{1}$ held by the central actors in each region

\begin{tabular}{|l|l|l|}
\hline Actor & Region 1 n ties & Region 2 $n$ ties \\
\hline RDA & 39 & 31 \\
\hline Stemnet & 21 & \\
\hline SEMTA & 20 & \\
\hline MNC6 & 10 & \\
\hline MNC 4 & 10 & \\
\hline MNC 18 & 10 & \\
\hline MNC33 & & 22 \\
\hline UKTI & & 16 \\
\hline MNC 34 & & 14 \\
\hline BIS & & 12 \\
\hline MNC25 & & 11 \\
\hline MNC32 & & 11 \\
\hline
\end{tabular}

Prominent Region 2 actors were BIS, UKTI, Ministers, and national sector skills groups, alongside the RDA, regional sector skills bodies and four lead MNCs (MNC32, ${ }^{1}$ ego network density measures 
Multinationals and skills policy networks

MNC25, MNC34 and MNC33). The multi-layered structural integration was different in Region 2, with direct presence of central government departments. R2 dominance in manufacturing was reflected in the four lead MNCs (see Table 1). The MNCs in the region were well known to each other and met regularly in a number of fora. One MNC Operations director (MNC32) explained there was co-operation because 'there is no competition between any of us as far as health and safety is concerned....certainly in the region we have all got different markets,.....we come from different market sectors so there is no conflict of interest'. The involvement of central government actors signalled accessibility to financial resources on a considerable scale. Direct involvement of the subsidiaries indicated an opportunity to shape the skills agenda. The MNCs were aware of the legitimacy they brought to the network:

R2, MNC33, HR director: We have strong relationships with the RDA and within the council we are seen as quite influential for them as a business voice.

We consider the structure of the connections and the potential for subgroups. The differentiation in membership of the networks reflect the different MNC skills issues in each of these regions (detailed in the methods). We could expect the institutional system and industrial path dependencies to have evolved differently, potentially a result of each of the actors' recursive learning. We can test this supposition of divergent sub-national institutional structures by examining the presence or absence of subgroups within the overall networks. Subgroup members would be more closely linked to each other than to other members of the overall network or to other subgroups. Comparing across Figures 1a and $1 b$ it is possible to identify 3 clear subgroups in R1 around the RDA, the regional branch of SEMTA and STEMNET. These actors are connected to others in a classic star shaped 
Multinationals and skills policy networks

formation, which reflects centralization of knowledge resources (Wasserman and Faust $1994)$ i.e. the governance actors appeared central in the gathering and distribution of information on labour market talent issues.

In R2 there were more sub-groupings with greater connectivity to each other. The star structure is complemented by a number of closed relationships indicative of strong ties between actors within these sub-groups. Closed structures are used when the members have something unique and of interest to others allowing the members to collaborate to cocreate outcomes which are jointly owned. These networks offer more potential for the MNC subsidiaries and other actors to jointly create talent management outcomes.

In summary, the power structure of the networks differed in terms of the centrality of MNCs compared to policy actors; and in terms of the spatial features of the regional skills space. On the first point, MNC actors where more central in R2 while the RDA, STEMNET and SEMTA were central in R1 and each of the three were central to sub-groups within the overall regional network. On the second point, R2 was a multi-level geographical space where national, regional and sub-regional actors connected directly with MNCs. R1 was spatially less eclectic.

\section{Network Structure: social content}

We turn to the motivation of the interaction to understand the ownership firms may seek to take. We look at network interaction such as influencing through lobbying, agenda setting or information sharing associated with loose ties, compared to joint actions that involve tight 
Multinationals and skills policy networks

ties associated with co-created skills activities. Table 2 summarises the power and content features of the networks and firms' strategic treatment of labour market skills.

Considering R1 first, the interview data suggest the interdependencies between the MNCs and the governance actors were weak, and aligned to information sharing and agenda setting activities. For example, the small high-tech MNCs skills strategy were dependent on recruiting from a local university, or buying-in from the global labour market. 
Multinationals and skills policy networks

Table 2: Network features and their influence on skill as a strategic resource: two sub-national MNC-Skills policy networks

\begin{tabular}{|c|c|c|c|}
\hline & Power structure & Social content & MNCs treatment of skill resources: outcomes \\
\hline Region 1 & $\begin{array}{l}\text { Membership: } \\
\text { - Uni-level - regional } \\
\text { - } \text { Diffuse skill interests } \\
\text { hirm competition for skill concerns to be } \\
\text { - Duplication of skills providers } \\
\text { Actor position and connections: } \\
\text { - Diffuse FDI-skill policy resources } \\
\text { - Segregated sub-clusters within the } \\
\text { network } \\
\text { - Policy actors key bridging and brokering } \\
\text { roles } \\
\text { - Low connectivity } \\
\text { Loose ties }\end{array}$ & $\begin{array}{l}\text { Content of tie: } \\
\text { MNC-skills policy actor: } \\
\text { - } \quad \text { To influence policy priorities/provision. } \\
\text { - } \quad \text { Firms focus on employee skills via firm } \\
\text { hierarchy. } \\
\text { - Past experience among MNC and policy } \\
\text { actors established familiarity and direct } \\
\text { personal relations, used to influence each } \\
\text { stakeholder, rather than jointly created } \\
\text { actions. } \\
\text { MNC-skills providers: } \\
\text { - Exchange focused on recruitment, } \\
\text { transaction training or research sponsorship; } \\
\text { influence on curriculum content. } \\
\text { - Separate sub-groups established due to } \\
\text { duplication of training provision allowing } \\
\text { MNCs to operate in different subgroups. } \\
\text { Skills policy actors-MNC: } \\
\text { Exchange concerned with organisational best } \\
\text { practice sharing; signposting; brokering. }\end{array}$ & $\begin{array}{l}\text { Largely exogenous resources: } \\
\text { - Network used to influence skills agenda } \\
\text { through formal/ informal involvement in } \\
\text { policy committees; identify recruitment } \\
\text { pools; influence curriculum content in } \\
\text { emerging technologies/subjects; share best } \\
\text { practice which reinforces voice in the } \\
\text { community; keep abreast of skill } \\
\text { innovations; access skills funding and } \\
\text { providers. }\end{array}$ \\
\hline
\end{tabular}


Multinationals and skills policy networks

\begin{tabular}{|c|c|c|c|}
\hline Region 2 & $\begin{array}{l}\text { Network membership: } \\
\text { - Multilevel, local, regional and national } \\
\text { - } \text { Policy actors high status due to access to } \\
\text { - Dominant MNC actors } \\
\text { - Complementary MNC skill interests } \\
\text { - Less duplication in resources } \\
\text { Actor position and connections: } \\
\text { - Sub-groups around both skills policy and } \\
\text { - MNC actors; and across subgroup } \\
\text { - } \quad \text { Tigh connectivity } \\
\text { - MNCs strong embedded structure }\end{array}$ & $\begin{array}{l}\text { Content of exchange: } \\
\text { MNC-skills policy actor: } \\
\text { - Stable personal and institutional relations in } \\
\text { locality enable recursive learning: strong } \\
\text { match between needs and funds to create } \\
\text { impact. } \\
\text { - Collaboration reputations amongst actors, as } \\
\text { a result firm's incorporated collaborative } \\
\text { structures. } \\
\text { - Hierarchy no longer sufficient as means of } \\
\text { training to scale required for some } \\
\text { subsidiaries. } \\
\text { MNCs have complimentary skill interest, } \\
\text { rather than direct competitors: smaller } \\
\text { MNCs invest in developing curriculum } \\
\text { content with national qualification provides } \\
\text { and larger MNCs oversupply training with } \\
\text { national skills funding. }\end{array}$ & $\begin{array}{l}\text { At least partially endogenous: } \\
\text { Network used to co-create outcomes through } \\
\text { joint working and reciprocal gains where: } \\
\text { 1. knowledge is currently absent and of long } \\
\text { term competitive value; } \\
\text { 2. it may not be cost or content effective if } \\
\text { pursued by one party alone, and where } \\
\text { availability of know-how required is limited; } \\
\text { 3. Firm moral imperative takes account of local } \\
\text { socio-economic issues. } \\
\text { - joint work in such instance may lead to } \\
\text { institutional innovations e.g. new } \\
\text { qualifications and create formal } \\
\text { contractual relations. } \\
\text { - Networks also to influence the policy } \\
\text { agenda and access skills as an } \\
\text { exogenous resource }\end{array}$ \\
\hline
\end{tabular}


Multinationals and skills policy networks

They therefore engaged in the skills network to retain direct contacts with STEMNET (the national science, technology, engineering and mathematics network with government funding) the RDA and universities. These members were seen as key skills governance actors with the intelligence needed by the firm on talent management trends to help them attract talent and technology innovations; and the MNC took part in events set up by these organisations and allowed agenda setting on talent challenges. For these governance bodies having the MNCs involved allowed them to ensure qualifications and training kept pace with competitive demands. Both the governance actors and MNC gained from the legitimacy of association. But the firms, because they were small, did not feel they had excessive financial or time resources to get involved in joint co-creation activities; information seeking for recruitment was the priority. The role of the RDA in R1, as one of the key governance actors, was therefore signposting, brokering and labour market intelligence on challenges. Thus 'touching base' (R1, MNC4, HR Director) with policy actors and vice versa was a key strand of network exchange, involving limited social transaction costs.

The network was critical as a space that enabled firms to connect, for example, with universities. A number of firms recruited local science and technology graduates or sponsored PhD work. For the firm this was a useful way to influence the university curriculum and equally the university departments benefitted from the reputation of securing quality graduate employment. Here too, the interaction did not involve the joint co-creation of curricula, instead it focused on building a mutual understanding amongst network actors of the types of skills that were deemed valuable and where they could be accessed. 
Multinationals and skills policy networks

However, the network did not work equally well for all its members, due in part to the diversity of firms and issues they face:

R1, MNC4, HR director: [the RDA in region $\mathrm{x}$ ] will actually go in to deliver the NVQ programme [national qualifications], they'll do the assessment, they'll do the verification, they'll run the scheme for you. Whereas the funding in [our area] tends to be through the partnership, like this triangle where you've got the funding organisation, your training partner, and they will come in and sort of guide you through it but you're there really to do the assessments and verification side. Can you successfully deliver an NVQ programme if you haven't got the internal structure there to support it?

Rather than the network focusing on a narrow set of issues, interaction focused on information sharing, gathering and brokering firm-skills provider connections. The firms held formal roles on local policy committees, but these tended to fall short of developing interorganisational collaboration structures in the policy-skills domain.

History between actors was significant, but reinforced brokering roles. Many of those working in the governance bodies either had a career history in the policy sector, or had sectoral expertise; some policy actors worked in the types of firms they were now collaborating with. Career paths often spanned the national and regional policy arena. The recursive learning this movement generated was seen to equip the policy actors with their ability to anticipate skills shifts or factory closures and challenge these firms to reinvest to create new capabilities (not always successfully); and frame diverse stakeholder interests to aid collaboration: 
Multinationals and skills policy networks

R1, SEMTA, Skills Manager: I've been with SEMTA two years at the end of this month. Prior to that I was with [Employers Federation].... Prior to that I worked in government, regional government as opposed to local government.... I like to think that's why we've managed to be able to help quite a number of companies, it's because of the contacts that we've got and I like to think the credibility that we've got in the region.

Thus although this skills network was concerned less with co-created activities, the familiarity amongst the actors meant there was considerable resource available to the network which was directed toward influencing priorities and brokering.

$\mathrm{R} 2$, by contrast, incorporated a number of skills projects collaboratively created by MNCs and qualification training providers with national and subnational funds. One such example involved MNCs and skills bodies co-creating a new qualification offerings:

R2, MNC34, Head of Apprenticeships: So when I was looking at the national occupational standards I was looking for ways to make sure I had in place the competencies that we are going to need for composites, built into the National Occupational Standards. So it's important that we are there working with [National Skills bodies] and influencing the direction that we want to take our skills strategy forward and SEMTA [national skills body] are a key organisation to support that...... we got MNC22 and MNC28 coming to meet with us to look at what we are doing and how we have developed some of the programmes for apprentices. I sit on a 'large engineering employer for apprenticeship group' where we are all talking about the challenges of the day. So when we are looking at the national occupational standards it won't be [us] there it will be MNC1, MNC23 and [other multinationals]. 
Multinationals and skills policy networks

In the above example, collaboration among the MNC and skills governance actors led to a new qualification. This collaboration required the firm to share their training expertise on composites i.e. their embodied knowledge linked to their competitive advantage on composite training, with the aim of encouraging other MNCs and skills actors to co-invest in skills, converting composite training into a public good. This was feasible because for the subsidiary to strengthen its strategic mandate within the MNC it needed to be able to secure sufficient composite skills at an affordable price. The lack of skills locally had meant the firm was reliant on high priced contractors who moved around the UK. These contractors were generalists who worked with composites in shipbuilding, but the handling requirements in aviation differed due to safety regulation, creating problems. The firm concerned was not large enough financially to bear the costs of training large numbers of employees who may then be lost to competitors. To reduce the risk for the firm and to increase their longer-term sustainability to win contracts from the parent, the benefits of converting their expertise and time in composite training to a public good out-weighted the costs. As one senior managers in MNC33 explained:

'the strength of the site is not the fact it has been here a long time, the strength of it is the fact that we have got the workforce who are capable of doing, producing the component within the right time, cost and to the quality that the [parent] expects. We are soon told if they don't feel that we are producing it in that order. It's the workforce skills that demonstrate to the [parent] centrally that we are the correct location'.

Similar sentiments regarding the significance of affordable skills to winning contracts within the MNC network were expressed across the firms we spoke with. The collaboration also required gaining buy-in from policy actors to develop new qualifications and buy-in 
Multinationals and skills policy networks

from larger MNCs in the region to incorporate new qualifications into their apprenticeship training. The movement from a job- training programme to a degree level apprenticeship programme took 10 years and the subsidiary had to persuade state actors of the merits because it did not easily fit the institutional structures: 'it was a bit of higher education and a bit of further education. So [government] didn't really accept that that was necessarily a route that was achievable through an apprenticeship' (MNC33 manager). Involvement of national policy actors in the region helped the firm promote understanding of the logic of the new qualification. This learning was shared across government departments and regions and eventually led to the region securing central government funds and backing of the large MNCs, which further reinforced investment of public funds. An area of interest going forward between the policy actors and some of the large firms was 'qualification for electric vehicles' (MNC Operations Director), particularly when many of the workforce may have been in the industry 30 years it becomes a dual concern for the firm and for the state that there is a strong supply of future skills.

The governance actors, in this example, had built up the knowledge and know-how to deliver firm needs as a result of a long history of working with the region. The relative deprivation in the region meant those working in the governance bodies were familiar with the needs of the region and its businesses. The firms were established in the region for many years. The individuals working in the firms or in the governance bodies had long tenure with either the organisation or the locality. In one firm the HR director (MNC33) spoke of how she used the Corporate Social Responsibility (CSR) objectives of the parent to focus community outreach activities around skills and sustainability which helped the business but also supported economic regeneration in the area. Through the local networks 
Multinationals and skills policy networks

CSR teams from other MNCs were focused on local issues 'be they educational or economic or community cohesion'. She noted the French sister subsidiary would focus CSR on the Arts but as she had a 'fair degree of autonomy' from the parent she was able to focus activities on the social concerns of the area e.g. upskilling, employment opportunities for disabled workers and long-term unemployed, work with schools to 'effect curriculum delivery through site visits, workshops, projects'. Another MNC HR Director explained his involvement with a range of regional policy actors using CSR as an umbrella concept adding: 'I do believe that there is the need to connect with the external community, whether it be government, education, facilities, charities...we, multinationals, have so much we can offer.... genuinely believe that we may have slightly different objectives but we are all primarily pushing along the same road. Which is to make the organisations that we work for, that we represent, as strong as they can be and provide a platform for growth and sustainability...and I have got to see one another as partners not necessarily as adversaries, you have got to build relationships' (MNC32).

Involvement, by the MNC community on the strategic partnerships with the councils was further used by managers to support social concerns through skills initiatives. The critical mass of firms with the same needs, which included the multinationals but also their supply chains, legitimized the governance actors investing resource in building internal capabilities to support these firms' needs and deliver policy outcomes on jobs and regional development. What we observed was thus a multi-level governance network that was able to pull in resource capability horizontally and vertically across the network to support the needs of its members; and who established social structures across the network that 
Multinationals and skills policy networks

retained the know-how and trust to engage. The governance actors were significant knowledge contributors to project-based activities, rather than merely brokers.

\section{Discussion}

We adopted an embeddedness perspective (Granovetter, 1985; Fligstein and Freeland, 1995) to examine the role of MNCs in skills policy networks. Theoretically, the embeddness perspective enabled closer scrutiny of the interplay of economic and social interests that evolve around the skills domain. This allowed us to move beyond organisational centric perspectives of HRM and to combine it with internationally comparative work on MNCs that takes greater account of the external institutional environment (Ferner, Edwards and $\underline{\text { Tempel, 2012) and social structure at local, as well as national levels (Morgan and }}$ Kristensen, 2006). employment relations perspectives on international organisation that take great account of locality and institution (Morgan???; Rutherford?? Phildo vou want to suggest any refs here and maybe something from the regions project). A key theoretical extension revealed from our whis work is the role of social structure as a casual mechanism

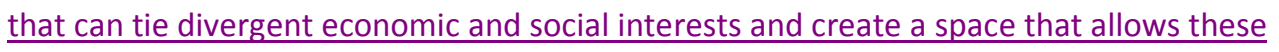
interests to be translated and constituted in actions that are understood and legitimate to diverse stakeholders. The presence of networks alone is insufficient to create multi-interest change or outcomes, instead the work here demonstrated that the capacity of network actors to 'frameming ' of fields within the social structure (Fligstein and McAdam, 2011) around 
Multinationals and skills policy networks

of the social structure by its members through ideas on economic sustainability and morale interest were critical.

Thus the research, Indoing so, asked the question of whether firms might seek to exert control over labour market skills in a way that goes beyond traditional HRM theorisation (Gardner, 2002). In the devolved policy context of the UK, it was evident that different social structures of MNC-policy engagement can emerge giving rise to local variants in subsidiary strategies to control external skill resources. This suggests theory development in HRM needs to take greater account of the networked nature of the subnational context. We evidence that where there is closer embedding of public and private logics around skills we see network participation framed around socio-economic issues. In high status, multi-level governance networks where social and economic growth are highly interdependent, path dependencies in the regional institutional arrangements can foster MNCs labour market skill strategies that are at least partially endogenous. We suggest two framing mechanisms are important here: a) economic sustainability, where longer term business benefits are gained by de-risking skill investment and strengthening the subsidiary's mandate position with the MNC; b) moral interest, where greater engagement by the firm in the subnational policy arena brings locality into focus opening opportunities for measuring and meeting performance beyond efficiency concerns alone. Recognising the social structure of policy and firm interactions reveals the recursive learning that takes place reinforcing a matching of resources and needs. The theoretical insight is that geographical sensitivity to the dynamics between firm strategy and sub-national institutional social-economic context can explain variation in how firms seek to control labour market resources and how economic behaviour is framed. This not only nuances our 
Multinationals and skills policy networks

theory of the significance of context to firm behaviour around people management, it also suggests where firms endogenize labour market skill the strategic value it plays shifts to firm performance outcomes that are longer-term and potentially societal.

Swart and Kinnie (2014: 294) emphasis that firms operate in networks to 'get things done' and as such it demands that HRM move beyond a model of owning employment relationships. Our work would not go so far as to indicate subsidiaries are willing to relinquish their ownership of HRM, but that they may be keen to extend it and that networks may provide a mechanism through which certain resources can be endogenized. We suggest motives for doing so may go beyond economic and efficiency reasons to reflect sensitivity to societal locational concerns.

The research revealed a number of specific findings. First, the network power structures within a national policy framework configured differently at subnational level. The co-ordinated multi-level policy response appeared to equalise the status of MNC and state actors in a way that arguably allowed greater co-construction of collaborative learning and innovation outcomes (Monaghan et al., 2015).

Second, in highly diverse networks, resource redundancy and resource competition which would theoretically mitigate against endogenising skills action (Tanis and Postmes, 2005; Yan et al 2015), may be offset through sub-clusters as these allow common concerns to coalesce and potential competitors to occupy different spaces within the network. For example, we found MNCs developed close relationships with local universities around the content of their degree programmes, which generated benefits for both parties: MNCs had a recruitment pipeline with qualifications containing job-relevant content; universities had an employability route for their students. 
Multinationals and skills policy networks

Third, despite volatility in the UK policy arena, the evidence suggests that career histories amongst those in both networks provided longevity to relationships within the network facilitating shared learning about available resources and needs of the network members. Phelps et al (2003) argue an important part of the embedding process is the ability of policy actors to engage meaningfully with MNCs. Our work suggests personal ties are subservient to the power structures of the network, which have their antecedents in historical path dependencies. The way in which policy actors engage meaningfully may be constrained by power structures that are more or less amenable to brokering or collaborative action. Recognising these different routes and their role in the embedding process provides insight into the actors for whom the networks may work best.

Our research yields insight for practice. For firms, research illustrates reticence amongst employers to move beyond immediate labour skill needs without policy actor support (Lewis, 2014). The work here provides a strategic framework for HR professionals to consider labour market involvement as a legitimate strategic activity. It advances previous research highlighting the demand on the HR community to move beyond functional HR boundaries to address significant strategic challenges (Bélanger, Edwards, and Wright, 1999). Operating at the nexus of economic and policy interests requires investment in this capability at both the individual and organisational level. Rethinking external labour markets as a partially endogenous MNC resource opens up the opportunity for firms to consider sustainable talent management strategies. Firm over-reliance on labour markets as extraction resource pools may be limiting.

For policy actors our work suggests that the greatest engagement with firms was achieved where the policy actors took on central co-ordination roles, and had access to 
Multinationals and skills policy networks

financial and knowledge resources that ensured they were high status network decision makers which the MNCs could see value in working with. Coupling financial and knowledge resources made engaging with the network much easier for MNCs. There was closer coordination of national, regional and local governance actors around FDI and skill concerns, plus movement of policy actors through policy organisations, to support recursive learning so state and firm interests more easily aligned. Where resources were diffuse across many stakeholders, leaving regional policy actors in brokering roles, the offering to MNCs was complex, confusing and perceived as irrelevant.

Future research could usefully examine how firms in general and HR professionals in particular develop the capabilities to deal with policy networks. At the firm level, there are structural and resourcing capacities that would enable organisational actors to bridge the connections between different groups and leverage or co-ordinate resources. How firms create such adaptive structures may be a critical feature of sustainable talent management strategies that contribute broader societal goals for the organisation (Beer et al 2015). At the individual level there are issues associated with the coordinating capabilities of individuals to operate effectively in what may be transient work-task spaces, but underpinned by relatively stable, but diverse stakeholder networks.

We would acknowledge that our work did not address distrust and conflict in networks. Through our use of embedded perspectives, we took greater account of the socio-economic environment and its relationship to firm behaviour. Nevertheless, there is clearly more work that could be done to consider the political and social conditions underpinning market behaviour (Fligstein and Mara-Drita, 1992).

\section{Conclusions}


Multinationals and skills policy networks

In conclusion, the skills arena will remain a central area of concern for firms and policy actors going forward. Availability of skills does not translate in an easy and linear manner to demand for those skills, instead we suggest the path needs to be and can be negotiated within a framework of economic and social concerns involving supply and demand side actors. Theoretically, a casual mechanism along this pathway is the social structure that ties and translates diverse interests. Using the UK as an example, we have seen a significant upskilling of the labour market since the 1980s (see Mason and RinconAznar, 2015). But the problems with social mobility remain; and the impact on national productivity has been mixed. Productivity grew faster for the UK compared to France, Germany or the US during the decade up to 2007, but has fallen back to levels at around a third lower than all three of these -countries (ONS Statistical Bulletin, 2015) due in part to structural shifts in the labour market arising from the growth of low-paid work and underemployment (Dolphin and Hatfield, 2015). Thus the skill supply strategy has had a variable impact on demand. However, our exploration of skills networks in the English context demonstrated that the interplay between firm and policy vested interests can, under certain conditions, lead to creative sustainable solutions. And as the Social Mobility Commission (2017) call for coalitions between firms, communities and policy to deliver more effective and widespread impact from public resources, it raises important questions about the skills and capabilities needed by those involved to work in this way. Brexit raises additional concerns, and particularly with regard to the ease with which firms can attract both high skilled and low skilled international labour to employment in the UK. Technological advances offer an opportunity to rethink how work is performed. As low skilled jobs may be replaced by technological advances we are also afforded the opportunity to create 
Multinationals and skills policy networks

innovations in work processes that allow the human resource to perform a more valuable job role. But innovation in how work is organised or designed in a more technologically advanced society demands creative solutions co-created by multiple vested interests. If the vested interests remain dominated by economic concerns alone our solutions are likely to fall short in attending to societal concerns. The HRM community in firms have a contribution to make in this regard. At the same time having strong intermediary organisations who represent vested social policy concerns around human resourcing utilisation is critical. Arguably, the need for multi-stakeholder coalitions to address common skill challenges around technology and job quality has never been greater, not only in the UK, but across the globalised economy. But the individual and organisational capabilities needed to work across policy-firm boundaries to meet both economic and social concerns of human capital is a necessary precursor to the success of such coalitions. 
Multinationals and skills policy networks

\section{References}

Almond, P., and Ferner, A. (2006). American multinationals in Europe. Oxford: Oxford University Press.

Almond, P, Ferner A. and Tregaskis, O. (2015). 'The changing context of regional governance of FDI in England', European Urban and Regional Studies, 22(1), pp.61-76.

Almond, P. (2011). 'The subnational embeddedness of HRM'. Human Relations, 64(4), pp. 531-551.Barney, J. (1991). 'Firm resources and sustained competitive advantage', Journal of Management, 17(1), pp. 99-120.

Beer, M., Boselie, P., \& Brewster, C. (2015). 'Back to the Future: Implications for the field of HRM of the Multistakeholder Perspective Proposed 30 Years Ago', Human Resource Management, 54(3), pp. 427-438.

Becker, B. and Gerhart, B. (1996). 'The impact of human resource management on organizational performance: progress and prospects', Academy of Management Journal, 39, pp. 779-801.

Bélanger, J., Edwards, P., and Wright, M (1999). 'Best HR Practice and the Multinational Company', Human Resource Management Journal, 9(3), pp. 53-70.

Brewster, C., Wood, G., and Brookes, M. (2008). 'Similarity, Isomorphism or Duality? Recent Survey Evidence on the Human Resource Management Policies of Multinational Corporations', British Journal of Management, 19, pp 320-342.

Boxall, P. F. (1996). 'The strategic HRM debate and the resource-based view of the firm', Human Resource Management Journal, 6(3), pp. 59-75. 
Multinationals and skills policy networks

Buckley, P. J. and Munjal, S. (2017). 'The Role of Local Context in the Cross-border Acquisitions by Emerging Economy Multinational Enterprises', British Journal of Management, 28(3), pp. 372-389.

Burt, R. (1983). Corporate Profits and Cooperation. New York: Academic Press.

Camps, J. and Luna-Arocas, R. (2012). 'A matter of learning: how human resources affect organizational performance', British Journal of Management, 23, pp. 1-21.

Coleman, J.S. (1988). 'Social Capital in the creation of human capital', American Journal of Sociology, 94, pp. 95-120.

Dolphin, T., and Hatfield, I. (2015). The missing pieces: Solving Britain's productivity puzzle, Institute of Public Policy Research Report.

Eisenhardt, K. M. and M. E. Graebner (2007). 'Theory building from case studies:

Opportunities and challenges', Academy of Management Journal, 50, pp. 25-32.

Ferner, A., Edwards, T. and Tempel, A. (2012). 'Power, institutions and the cross-national transfer of employment practices in multinationals', Human Relations, 65, pp.163-187.

Fligstein, N. (1990). The Transformation of Corporate Control. Cambridge, MA: Harvard University Press.

Fligstein, N. (1996). 'Markets as politics: a political-cultural approach to market institutions', American Sociological Review, 61, pp. 657-673.

Fligstein, N. and Freeland, R. (1995). 'Theoretical and comparative perspectives on corporate organisation', Annual Review of Sociology, 21, pp. 21-43.

Fligstein, N. and McAdam, D., (2012). A theory of fields. Oxford: Oxford University Press.

Formatted: Font: Not Italic 
Multinationals and skills policy networks

Fligstein, N. and Sweet, A. S. (2002). 'Constructing polities and markets: an institutionalist account of European integration.' American Journal of Sociology, 107(5), pp. 1206-43.

Fombrun, C., Tichy, N. M. and Devanna, M. A. (1984). Strategic Human Resource

Management. New York: John Wiley and Sons.

Gammelgaard, J., McDonald, F., Tüselmann, H., Dörrenbächer, C., and Stephan, A. (2009).

'Subsidiary role and skilled labour effects in small developed countries', Management International Review, 49, pp. 27-42.

Gardner, T. M. (2002). 'In the trenches at the talent wars: competitive interaction for scarce human resources'. Human Resource Management, 41(2), pp. 225-237.

Goodwin, M., Jones, M. and Jones, R. (2005). ‘Devolution, constitutional change and economic development: explaining and understanding the new institutional geographies of the British State'. Regional Studies, 39(4), pp. 421-436.

Granovetter, M. (1985). 'Economic action and social structure: the problem of embeddedness', American Journal of Sociology, 91(3), pp. 481-510.

Hall, P. and Soskice, D. (2001). Varieties of Capitalism. Oxford: Oxford University Press. House of Commons (2015) Education, Skills and Productivity: commissioned research. London: The Stationery Office Ltd.

Huselid, M. A. (1995). 'The impact of human resource management practices on turnover, productivity, and corporate financial performance', Academy of Management Journal, 38(3), pp. 635-72. 
Multinationals and skills policy networks

Keep, E. (2014). 'What does skills policy look like now the money has run out?' SKOPE, ESRC Centre on Skills, Knowledge \& Organisational Performance: Oxford.

Keep, E. and Mayhew, K. (2010). 'Moving beyond skills as a social and economic panacea', Work, Employment and Society, 24(4), pp. 565-577.

Lewis, P. (2014). 'The over-training of apprentices by employers in advanced manufacturing: a theoretical and policy analysis', Human Resource Management Journal, 24(4), pp. 496513.

March, J. and Olsen, J. (1989). Rediscovering Institutions. New York: Free Press.

Marsh, D. and Rhodes, R.A.W (1992). Policy Networks in British Government. Oxford: Clarendon Press.

Mason, G. and Rincon-Aznar, A. (2015). Skills and Productivity in the UK, US, France and Germany: a literature review. Report to the Business, Innovation and Skills and Education Select Committees, House of Commons, $26^{\text {th }}$ October 2015.

McDonald, F. et al (2005). 'The strategic development of foreign owned subsidiaries and employment in host locations in the UK', Environment and Planning C: Government and Policy, 23(6), pp. 867-882.

Michie, J. and Sheehan-Quinn, M. (2001). 'Labour market flexibility, human resource management and corporate performance', British Journal of Management, 12, pp. 287-306.

Miles, M. B. and A. M. Huberman (1994). Qualitative Data Analysis, 2nd edn. Thousand Oaks, CA: Sage. 
Multinationals and skills policy networks

Monaghan, S. Gunnigle, P. and Lavelle, J (2014). 'Courting the multinational: Subnational institutional capacity and foreign market insidership', Journal of International Business Studies, 45, pp. 131-150.

Morgan, G. and Kristensen, P. H. (2006). 'The contested space of multinationals: varieties of institutionalism, varieties of capitalism'. Human Relations, 59(11), pp. 1467-1490.

Muller, M. (1999). 'Human Resource Management under institutional constraints: the case of Germany', British Journal of Management, 10, pp. s31-s44.

Murmann, J. P. (2013). 'The coevolution of industries and important features of their environments', Organization Science, 24(1), pp. 58-78.

ONS (2015), International Comparisons of Productivity - First Estimates 2014, London: Office for National Statistics.

Pemberton, H. (2000). 'Policy networks and policy learning: UK economic policy in the 1960s and 1970s', Public Administration, 78(4), pp. 771-792.

Phelps, N. (2008). 'Cluster or capture? Manufacturing foreign direct investment, external economies and agglomeration', Regional Studies, 42(4), pp. 457-73.

Phelps, N., MacKinnon, D., Stone, I. and Braidford, P. (2003). 'Embedding the multinationals? Institutions and the development of overseas manufacturing affiliates in Wales and North East England', Regional Studies, 37(1), pp. 27-40.

Phelps N, Valler, D. and Wood, A. (2005). 'Stealing the skills agenda? Devolution, business and post-16 education and training in Wales', Policy and Politics 33(4), pp. 559-579. 
Multinationals and skills policy networks

Rhodes, R. (2007). 'Understanding Governance: Ten Years On', Organization Studies, 28, pp. 1243-1264.

Social Mobility Commission (2017). Time for change: an assessment of government policy on social mobility 2097-2017.

Schuler, R. and Jackson, S. E. (1987). 'Linking competitive strategies with human resource management practices', Academy of Management Executive, 3.

Swart, J. and Kinnie, N. (2014). 'Reconsidering boundaries: human resource management in a networked world', Human Resource Management, 53(2), pp. 291-310.

Tanis, M. and Postmes, T. (2005). 'A social identity approach to trust: Interpersonal perception, group membership and trusting behaviour', European Journal of Social Psychology, 35, pp. 413-24.

Tregaskis, O., Daniels, K, Glover, L., Butler, P., and Meyer, M. (2013). 'High Performance Work Practices', British Journal of Management, 24(2), pp.225-244.

Tregaskis O., Edwards T., Edwards P., Ferner A. and Marginson P. (2010). 'Transnational learning structures in multinational firms: organisational context and national embeddedness', Human Relations, 63(4), pp. 471-499.

Understanding Societies Survey Data, 2008-14. ESRC Datasets.

Wasserman, S. and Faust, K. (1994). Social Network Analysis. Cambridge: CUP.

Williamson, O. (1975). Markets and Hierarchies. New York: Free Press. 
Multinationals and skills policy networks

Williamson, O. and Ouchi, W. (1981). 'The Markets and Hierarchies and Visible Hand Perspectives', In Andrew Van de Ven and William Joyce (eds) Perspectives on Organizational Design and Behavior, pp. 347-70. New York: Wiley.

Yan. M., Francesco, A. M., Zhang, H. and Chen, Y. (2013). 'Examining the moderating impact of HR task interdependence', Human Resource Management, 52(4), pp. 585-606. 
Multinationals and skills policy networks

\section{Appendix}

Table A1: Key for the visual maps and definitions of the M-GA network members, with \% of organisations represented in each region

\begin{tabular}{|c|c|c|c|}
\hline symbol & Type of organisation & & $\%$ \\
\hline & $\begin{array}{l}\text { Private enterprise actors: } \\
\text { MNC1-29 -multinational companies. }\end{array}$ & 15 & 9 \\
\hline$\bullet$ & $\begin{array}{l}\text { National policy actors on skills: } \\
\text { BIS - Government Department for Business, Innovation and Growth. } \\
\text { UKTI -UK Trade and Industry, responsible to attracting and retaining FDI. } \\
\text { UKTI-Int - subunit focused on attracting FDI to the region. } \\
\text { Borders Agency - working closely with UKTI } \\
\text { SFA - Skills Funding Agency partner organisation of BIS responsible for funding adult education in England. } \\
\text { STEMNET - Science, Technology, Engineering and Mathematics network, funded by BIS and the Department of Education, to } \\
\text { promote STEM opportunities to young people. } \\
\text { NSA - National Skills Academies, funded by the SFA, employer led to support training. } \\
\text { NAS - National Apprenticeship Service in England. } \\
\text { JobC+ - Job Centre plus, a government service to help the unemployed into work. } \\
\text { NCETM - National Centre for Excellence in Teaching Mathematics, National STEM network to support teachers. } \\
\text { MyScience, part of the STEM network of organisations in the UK. }\end{array}$ & 9 & 8 \\
\hline
\end{tabular}


Multinationals and skills policy networks

\begin{tabular}{|c|c|c|c|}
\hline & $\begin{array}{l}\text { HEFCE - Higher Education Funding Council for England distributes public funds for education. } \\
\text { SSC - Sector Skills Council, responsible for delivery of training solutions. Two of particular relevance to this work were } \\
\text { SEMTA Sector Skills Councils for Manufacturing, Engineering and Sciences; COGENT Sector Skills Council for Chemicals, } \\
\text { Nuclear, Oil and Gas, Petroleum and Polymers. } \\
\text { Ministers - elected members of parliament with ministerial responsibilities. }\end{array}$ & & \\
\hline 口 & $\begin{array}{l}\text { Sub-national (Regional) policy on business growth and skills: } \\
\text { RDA - Regional Development Agency, devolved administration responsible for driving economic growth at the regional level. } \\
\text { RDA-Int - international unit focusing on FDI to the region. } \\
\text { Business Link - government service to support development of businesses. } \\
\text { Manufacturing Advisory Service (MAS), regional office, funded by BIS to provide business support. } \\
\text { Learning and Skills Council (LSC), regional office, responsible for helping businesses grow through skills training, later } \\
\text { replaced by the national SFA. } \\
\text { National Skills Academy, regional office. } \\
\text { SSC - Sector Skills Council, regionally office for SEMTA and COGENT } \\
\text { Train to Gain - regional office, Government initiative funded through The Skills Enhancement aimed at vocational training } \\
\text { primarily for the } 25+\text { year olds. } \\
\text { Job centre plus, regionally office. } \\
\text { Connexions - government initiative to provide free careers advise to individuals. } \\
\text { Union1-2 - local offices of Union Learn or union bodies supporting training to secure future employment. }\end{array}$ & 10 & 9 \\
\hline+ & $\begin{array}{l}\text { University actors on Innovation, R\&D, niche skills. } \\
\text { HEI1-10 - Higher Education Institutions provide highly skilled human capital or R\&D projects. }\end{array}$ & 7 & 5 \\
\hline
\end{tabular}


Multinationals and skills policy networks

\begin{tabular}{|c|c|c|c|}
\hline$\Delta$ & $\begin{array}{l}\text { Local skilled labour market actors: } \\
\text { FE1-4 - Further Education, i.e. local colleges providing skill labour. } \\
\text { Train1-3 - private training companies employed to deliver government funded training. }\end{array}$ & 4 & 3 \\
\hline $\bar{\Delta}$ & $\begin{array}{l}\text { Employer led human capital development actors: } \\
\text { EMPA1-5 - local offices/representatives of Employer led associates such as Engineering Employers Federation, } \\
\text { Confederation of British Industry (CBI). Focused on promoting an employer driven skills agenda. }\end{array}$ & 4 & 1 \\
\hline D & $\begin{array}{l}\text { Local (sub-regional) political agenda on economic growth and skills: } \\
\text { LA - Local Authority, local political structure responsible for delivering public services. } \\
\text { City Council -political structure at the city level, with FDI specialist or council led initiatives to support businesses. } \\
\text { L-MP1-2 - locally elected members of parliament. } \\
\text { L-community - local community action groups. } \\
\text { L-Chamber1-4 - local Chambers of Commerce, providing business support and lobby government. } \\
\text { SR-Partnership1-4 - sub-regional partnerships between the local council, private firms and other relevant issue based } \\
\text { stakeholders. }\end{array}$ & 3 & 6 \\
\hline
\end{tabular}

